\title{
Hubungan Teknik Menyikat Gigi dengan Keparahan Resesi Gingiva pada Masyarakat Pesisir Pantai di Kawasan Megamas Kota Manado
}

\author{
Lilies Rizkika \\ Christy N. Mintjelungan \\ Kustina Zuliari \\ Johanna Khoman \\ Program Studi Pendidikan Dokter Gigi Fakultas Kedokteran \\ Universitas Sam Ratulangi Manado \\ Email: kikycpsi@gmail.com
}

\begin{abstract}
Gingival recession is the displacement of marginal gingiva to the apical direction of the cementoenamel junction due to the loss of alveolar bone attachment tissue resulting in exposure of the root surface of the tooth. Wrong technique of tooth brushing is one of the causes of gingival recession. This study was aimed to determine the correlation between tooth brushing techniques and gingival recession among the coastal coast community at the Megamas area of Manado. This was an analytical study with a cross sectional design. Sampleswere obtained by using total sampling method. Tooth brushing techniques were observed by looking at the way the respondents brushed their teeth. We provided check lists in accordance with the techniques they used. Data of gingival recession were obtained by examination of the oral cavity and then we calculated the severity of gingival recession. There were 43 respondents involved in this study. The result of the Kolmogorov-Smirnov obtained a p-value of 0.000 . In conclusion, Yjere was a relationship between tooth brushing technique and the severity of gingival recession.
\end{abstract}

Keywords: gingival recession, tooth brushing technique

\begin{abstract}
Abstrak: Resesi gingiva adalah perubahan posisi tepi gingiva ke arah apikal dari cemento enamel junction karena hilangnya jaringan perlekatan tulang alveolar sehingga mengakibatkan terbukanya permukaan akar gigi. Kesalahan teknik menyikat gigi merupakan salah satu penyebab resesi gingiva. Penelitian ini bertujuan untuk mengetahui hubungan teknik menyikat gigi dengan keparahan resesi gingiva pada masyarakat pesisir pantai di Kawasan Megamas Kota Manado. Jenis penelitian ialah analitik dengan desain potong lintang. Pengambilan sampel dilakukan dengan metode total sampling. Pengambilan data dilakukan dengan cara melihat gerakan menyikat gigi yang digunakan. Hasil pengamatan dimasukkan ke dalam check list sesuai dengan teknik yang digunakan. Resesi gingiva yang diperoleh melalui pemeriksaan langsung diklasifikasikan menurut tingkat keparahan resesi gingiva. Jumlah responden dalam penelitian ini sebanyak 43 orang. Hasil analisis menggunakan uji Kolmogorov-Smirnov mendapatkan nilai $\mathrm{p}=0,000$. Simpulan penelitian ini menunjukkan adanya hubungan teknik menyikat gigi dengan keparahan resesi gingiva.
\end{abstract}

Kata kunci: resesi gingiva, teknik menyikat gigi

Penyakit periodontal merupakan penyakit mulut yang sering ditemui dengan insidensi mencapai $15 \%-20 \%$ dari populasi dewasa di dunia. ${ }^{1}$ Penyakit periodontal adalah suatu keadaan patologis yang mengenai jaringan pendukung gigi dan bersifat kronis sehingga keluhan atau gejala yang timbul baru disadari oleh penderita bila keadaan sudah lanjut. Prevalensi penyakit periodontal di Indonesia sebesar 73,1-75\%. ${ }^{2}$ 
Penyakit periodontal yang sering terjadi dan menimbulkan masalah pada pasien yaitu gingivitis dan periodontitis. Periodontitis akan mengakibatkan terbentuknya ruang antara gingiva dan gigi, serta hilangnya serat ikat dan tulang di sekitar akar gigi sehingga dapat menyebabkan resesi gingiva dan keroposnya tulang. Resesi gingiva merupakan pergeseran atau pergerakan margin gingiva ke arah apikal yang mengakibatkan terbukanya permukaan akar gigi sehingga secara estetik tampak tidak indah. Resesi gingiva dapat terjadi secara fisiologis dan patologis. Resesi yang bersifat fisiologis berhubungan dengan faktor usia sedangkan resesi gingiva yang bersifat patologis berhubungan dengan malposisi, inflamasi gingiva, dan perlekatan frenulum yang abnormal. ${ }^{3}$

Faktor lain yang dapat menjadi penyebab resesi gingiva yaitu teknik menyikat gigi yang tidak tepat. Teknik menyikat gigi yang sering digunakan tidak tepat yaitu teknik menyikat gigi horizontal dan vertikal, kesalahan dalam menyikat gigi menggunakan teknik ini secara agresif lambat laun menyebabkan resesi gingiva. ${ }^{4}$ Resesi gingiva dapat menyebabkan berbagai masalah seperti masalah estetik, karies pada permukaan akar gigi, dan hipersensivitas dentin. Hasil penelitian yang dilakukan oleh Tezel di Turki menunjukkan bahwa adanya hubungan yang signifikan antara resesi gingiva dengan frekuensi, durasi, dan teknik menyikat gigi. ${ }^{5}$

Sulawesi Utara merupakan salah satu provinsi yang terbentang dengan rangkaian pegunungan, dataran tinggi, dan pesisir pantai yang luas. Kegiatan ekonomi masyarakat sangat bergantung pada sumber daya alam yang dimiliki daerahnya sehingga sebagian besar penduduk dataran tinggi memanfaatkan hasil alam seperti bertani dan berkebun. Penduduk pesisir pantai sebagian besar bergantung pada hasil perikanan yaitu berprofesi sebagai nelayan. ${ }^{6}$

Nelayan merupakan salah satu profesi dalam suatu kelompok masyarakat yang membutuhkan waktu yang lama dalam bekerja dan meninggalkan rumah pada sore hari dan kembali pada pagi hari. Nelayan mengalami kesulitan dalam menjaga kebersihan gigi dan mulut karena saat bekerja di laut nelayan berjaga sepanjang malam dan saat berjaga mereka makan, minum, maupun merokok untuk menghilangkan rasa kantuk. Kebersihan gigi dan mulut yang rendah, kurangnya kesadaran dan pengetahuan terhadap kesehatan gigi dan mulut, serta teknik menyikat gigi yang tidak tepat dapat menyebabkan resesi gingiva.

Berdasarkan latar belakang tersebut, peneliti tertarik untuk melakukan penelitian mengenai hubungan teknik menyikat gigi dengan keparahan resesi gingiva pada masyarakat pesisir pantai di Kawasan Megamas Kota Manado.

\section{METODE PENELITIAN}

Penelitian ini dilaksanakan pada bulan Maret-April 2019 di Kawasan Megamas Kota Manado. Jenis penelitian ialah analitik dengan menggunakan desain potong lintang. Populasi penelitian ini ialah kelompok nelayan tradisional di pesisir pantai Kawasan Megamas Kota Manado yang berjumlah 43 orang. Jumlah sampel dalam penelitian ini sebanyak 43 orang diambil berdasarkan metode total sampling yang memenuhi kriteria inklusi dan ekslusi.

Teknik menyikat gigi yang dimak-sud dalam penelitian ini yaitu teknik menyikat gigi yang digunakan responden dalam kesehariannya kemudian ditentukan apakah termasuk teknik menyikat gigi horizontal, vertikal, bass, dan modifikasi stillman.

Keparahan resesi gingiva yaitu tingkat keparahan resesi gingiva yang diderita responden. Penilaian keparahan resesi gingiva dibagi menjadi empat kelas yaitu kelas I Miller, kelas II Miller, kelas III Miller, dan kelas IV Miller.

Instrumen dan alat penelitian yang digunakan dalam penelitian ini ialah lembar check list teknik menyikat gigi, lembar pemeriksaan indeks resesi gingiva, kaca mulut, masker, sarung tangan, dan kamera.

Peneliti terlebih dahulu memberikan surat izin dari Program Studi Kedokteran Gigi Unsrat ke kelompok nelayan 
tradisonal di Kawasan Megamas Kota Manado, kemudian menjelaskan tujuan penelitian kepada calon responden dan ditanyakan kesediannya untuk menjadi responden penelitian dengan memberikan informed concent.

Untuk mengetahui teknik menyikat gigi yang digunakan, responden diminta memperagakan teknik menyikat gigi yang digunakan sehari-hari. Setelah memperagakan teknik menyikat gigi, dilakukan pemeriksaan secara langsung di rongga mulut responden menggunakan kaca mulut untuk mengetahui tingkat keparahan resesi gingiva yang diderita.

Data penelitian ini kemudian dianalisis menggunakan Statistical Product and Service Solution (SPSS) 25. Analisis hubungan teknik menyikat gigi dengan keparahan resesi gingiva menggunakan uji Kolmogorov-Smirnov.

\section{HASIL PENELITIAN}

Penelitian ini dilakukan pada kelompok nelayan tradisonal di pesisir pantai Kawasan Megamas, Kota Manado, Provinsi Sulawesi Utara. Nelayan-nelayan di sini terbagi dalam empat kelompok, yaitu kelompok nelayan Bintang Laut, Karang Putih, Tarusi, dan Firdaus Manado. Jumlah seluruh anggota dalam kelompok nelayan tradisional di Kawasan Megamas, yaitu 43 orang yang terdiri atas 13 orang dari kelompok nelayan Bintang Laut, 10 orang dari kelompok nelayan Karang putih, 10 orang dari kelompok nelayan Tarusi, dan 10 orang dari kelompok nelayan Firdaus Manado. Semua responden penelitian berjenis kelamin laki-laki.

Tabel 1 menunjukkan distribusi responden berdasarkan usia. Yang terbanyak ialah responden yang berusia 45-49 tahun $(76,8 \%)$. Tidak ada responden yang berusia 17-29 tahun.

Tabel 2 menunjukkan responden yang menempati posisi tertinggi terdapat pada responden yang menggunakan teknik menyikat gigi horizontal sebesar 56,0\%. Tidak ada responden yang menggunakan teknik menyikat gigi bass dan modifikasi Stillman.
Tabel 1. Distribusi responden berdasarkan usia

\begin{tabular}{ccc}
\hline Usia (Tahun) & $\mathbf{n}$ & $\mathbf{\%}$ \\
\hline $17-29$ & 0 & 0 \\
$30-44$ & 10 & 23,2 \\
$45-49$ & 33 & 76,8 \\
Total & 43 & 100 \\
\hline
\end{tabular}

Tabel 2. Distribusi responden berdasarkan teknik menyikat gigi

\begin{tabular}{lcc}
\hline Teknik Menyikat Gigi & n & \% \\
\hline Horizontal & 24 & 56,0 \\
Vertikal & 19 & 44,0 \\
Bass & 0 & 0,0 \\
Modifikasi stillman & 0 & 0,0 \\
Total & 43 & 100 \\
\hline
\end{tabular}

Tabel 3 menunjukkan distribusi responden berdasarkan resesi gingival. Resesi gingiva kelas IV menempati posisi tertinggi $(46,5 \%)$ dan posisi terendah resesi gingiva kelas I $(4,7 \%)$.

Tabel 3. Distribusi responden berdasarkan resesi gingiva

\begin{tabular}{lcc}
\hline Klasifikasi Resesi Gingiva & n & \% \\
\hline Kelas I & 2 & 4,7 \\
Kelas II & 5 & 11,6 \\
Kelas III & 16 & 37,2 \\
Kelas IV & 20 & 46,5 \\
Total & 43 & 100 \\
\hline
\end{tabular}

Tabel 4 menunjukkan keparahan resesi gingiva berdasarkan teknik menyikat gigi, diketahui bahwa teknik menyikat gigi horizontal menyebabkan resesi gingiva kelas IV menempati posisi tertinggi $(44,2 \%)$ dan posisi terendah ditempati oleh teknik menyikat gigi vertikal menyebabkan resesi gingiva kelas IV (2,3\%). Hasil analisis uji Kolmogorov-Smirnov memperoleh nilai $\mathrm{p}=0,000(\mathrm{p}<0,05)$ yang menunjukkan terdapat hubungan teknik menyikat dengan keparahan resesi gingiva.

\section{BAHASAN}

Penelitian ini yang bertujuan untuk mengetahui hubungan teknik menyikat gigi dengan keparahan resesi gingiva pada masyarakat pesisir pantai di Kawasan Megamas Kota Manado. 
Tabel 5. Keparahan resesi gingiva berdasarkan teknik menyikat gigi

\begin{tabular}{lccccccccccc}
\hline \multirow{1}{*}{\multicolumn{1}{c}{ Teknik }} & \multicolumn{10}{c}{ Resesi gingiva } \\
\multicolumn{1}{c}{ menyikat gigi } & \multicolumn{2}{c}{ Kelas I } & \multicolumn{2}{c}{ Kelas II } & \multicolumn{2}{c}{ Kelas III } & \multicolumn{2}{c}{ Kelas IV } & Tota & \multirow{2}{*}{ Nilai } \\
& $\mathrm{n}$ & $\%$ & $\mathrm{n}$ & $\%$ & $\mathrm{n}$ & $\%$ & $\mathrm{n}$ & $\%$ & $\mathbf{l}$ & $\mathbf{p}$ \\
\hline Horizontal & 0 & 0 & 0 & 0 & 5 & 11.6 & 19 & 44,2 & 24 & 0,000 \\
Vertikal & 2 & 4,7 & 5 & 11,6 & 11 & 25,6 & 1 & 2,3 & 19 & \\
Bass & 0 & 0 & 0 & 0 & 0 & 0 & 0 & 0 & 0 & \\
Modifikasi stilman & 0 & 0 & 0 & 0 & 0 & 0 & 0 & 0 & 0 & \\
\hline
\end{tabular}

Seluruh responden berjenis kelamin laki-laki. Pekerjaan nelayan yang penuh dengan risiko yaitu menangkap ikan di laut yang bahkan bisa berhari-hari biasanya dikerjakan oleh laki-laki sementara perempuan akan mengurusi rumah tangga dan untuk membantu perekonomian keluarga. Mereka akan menjual hasil tangkapan ikan di pasar.

Dari hasil penelitian juga didapatkan bahwa seluruh responden mengalami resesi gingival. Hal ini dapat disebabkan karena kurangnya kesadaran dan pengetahuan nelayan mengenai kebersihan gigi dan mulut. Hasil penelitian ini didukung oleh penelitian dari Chrysanthakopoulos di Yunani $^{7}$ yaitu 336 responden laki-laki seluruhnya mengalami resesi gingiva (100\%). Juga penelitian dari Hamamci dan Svedstrom ${ }^{8}$ di Turki yang menyatakan lakilaki lebih menerima keberadaan estetika gingiva dibandingkan dengan perempuan.

Tabel 1 menunjukkan bahwa kelompok usia nelayan terbanyak yaitu usia 4559 tahun berjumlah 33 orang $(76,8 \%)$. Hal ini dikarenakan nelayan muda (berusia $<45$ tahun) menganggap profesi nelayan sudah tidak menguntungkan sebab harga ikan yang tidak menentu dengan tidak adanya jaminan akses pasar, sarana dan prasarana tidak memadai sehingga kurang mampu bersaing dengan nelayan yang mempunyai peralatan tangkap lebih modern sehingga nelayan berusia muda lebih memilih menjadi buruh di kota-kota besar. ${ }^{9}$ Hasil penelitian ini selaras dengan penelitian yang dilakukan oleh Rakhmanda ${ }^{10}$ di Yogyakarta yang mendapatkan paling banyak nelayan berusia di atas 45 tahun sebesar $70 \%$.
Tabel 2 menampilkan distribusi responden berdasarkan teknik menyikat gigi yang digunakan. Responden hanya menggunakan teknik menyikat gigi hori-zontal dan vertikal dalam keseharian mereka. Teknik menyikat gigi yang paling banyak digunakan oleh responden yaitu teknik meyikat gigi secara horizontal (56\%). Kedua teknik tersebut cukup sederhana, umum digunakan dan mudah dikuasai tanpa harus memerlukan latihan khusus sehingga banyak digunakan sebagai teknik menyikat gigi sehari-hari. Sesuai dengan penelitian yang dilakukan oleh Siregar ${ }^{11}$ di Medan dari 65 responden didapatkan hanya menggunakan teknik menyikat gigi horizontal dan vertikal saja yaitu 42 responden menggunakan teknik menyikat gigi horizontal $(64,6 \%)$ dan 23 responden menggunakan teknik menyikat gigi vertikal $(35,4 \%)$.

Tabel 4 memperlihatkan distribusi responden berdasarkan klasifikasi resesi gingiva menunjukkan dari 43 responden, paling banyak mengalami resesi kelas IV $(46,5 \%)$. Hal ini dapat disebakan karena kesulitan nelayan dalam menjaga kebersihan gigi dan mulut. Nelayan bekerja dengan waktu yang bervariasi, kadang pagi hingga sore atau bahkan dapat sehari semalam di lautan. Saat berjaga sepanjang malam, mereka makan, minum, maupun merokok untuk menghilangkan rasa kantuk sehingga kurangnya kebersihan gigi mulut pada malam hari padahal kebersihan gigi dan mulut pada malam hari merupakan suatu hal yang penting sebab laju saliva akan menurun dan efek protektif saliva akan berkurang dan memengaruhi proses demineralisasi dan remineralisasi pada 
gigi. $^{12}$ Saliva berperan penting dalam proses pencegahan karies, berkurangnya sekresi saliva dapat mengurangi kemampuan membersihkan rongga mulut, meningkatkan pertumbuhan plak dimana seiring berjalannya waktu, plak lamakelamaan akan menjadi kalkulus yang dapat menyebabkaan kehilangan perlekatan jaringan gingiva, dan lebih lanjut menyebabkan resesi gingiva. ${ }^{13}$ Selain itu beberapa faktor seperti pendidikan, ekonomi, kebiasaan, dan lingkungan dapat memengaruhi oral hygiene. Sesuai dengan hasil penelitian yang dilakukan oleh Asmara $^{14}$ pada masyarakat pesisir pantai di Makassar didapatkan paling banyak mengalami resesi gingiva kelas IV Miller sebesar 33,3\%.

Tabel 5 memperlihatkan keparahan resesi gingiva berdasarkan teknik menyikat gigi. Sebagian besar responden menggunakan teknik menyikat gigi horizontal yaitu sebesar $56 \%$ dan rata-rata responden mengalami resesi gingiva kelas IV. Hal ini biasa terjadi disebabkan karena tekanan yang keras saat menyikat gigi dimana jika dilakukan terus-menerus dapat menyebabkan resesi gingiva. Hasil penelitian ini didukung oleh beberapa penelitian sebelumnya yang menyatakan bahwa teknik menyikat gigi secara horizontal merupakan salah satu penyebab resesi gingival. Penelitian yang dilakukan oleh Chrysanthakopoulus $^{7}$ di Yunani yang mendapatkan hasil bahwa menyikat gigi dengan teknik horizontal dapat menyebabkan cedera pada jaringan lunak yang menyebabkan resesi gingiva. Hasil penelitian ini sejalan dengan pernyataan Rateitschack ${ }^{15}$ bahwa salah satu faktor yang mungkin dapat menyebabkan resesi gingiva yaitu menyikat gigi secara horizontal. Hasil penelitian ini juga menunjukkan $44 \%$ responden menggunakan teknik menyikat gigi vertikal dan mengalami resesi gingiva kelas I, kelas II, kelas III dan kelas IV. Hal juga biasanya disebabkan karena tekanan yang keras saat menyikat gigi sehingga bagian servikal gigi juga berisiko mengalami resesi gingiva. Penelitian yang dilakukan oleh Beltran ${ }^{16}$ di Amerika Selatan melaporkan bahwa dari
115 responden yang berusia 35-50 tahun sebesar $79,1 \%$ responden menggunakan teknik menyikat gigi vertikal dan mengalami resesi gingiva. Teknik menyikat gigi horizontal lebih banyak menyebabkan resesi gingiva dibandingkan dengan teknik menyikat gigi secara vertical. Hal ini juga didukung oleh penelitian yang dilakukan oleh Sitananya ${ }^{17}$ di Sulawesi Selatan terhadap 40 responden yang mendapatkan 17 responden mengalami resesi gingiva karena menggunakan teknik menyikat gigi horizontal $(42,5 \%)$ dan 6 responden mengalami resesi gingiva karena menggunakan teknik menyikat gigi vertikal (15\%).

Berdasarkan hasil analisis bivariat menggunakan uji statistik KolmogorovSmirnov yaitu untuk menganalisis hubungan teknik menyikat gigi dengan keparahan resesi gingiva dengan menggunakan program SPSS, menunjukan hasil nilai $\mathrm{p}=$ $0,000(\mathrm{p}<0,05)$. Hal ini berarti terdapat hubungan teknik menyikat gigi dengan keparahan resesi gingiva dimana teknik menyikat gigi yang salah akan menyebabkan cedera pada jaringan lunak yang menyebabkan resesi gingiva.

\section{SIMPULAN}

Berdasarkan hasil penelitian terhadap kelompok nelayan tradisional di pesisir pantai Kawasan Megamas Kota Manado ini dapat disimpulkan bahwa terdapat hubungan bermakna antara teknik menyikat gigi dengan keparahan resesi gingival.

Penyuluhan mengenai kesehatan gigi dan mulut perlu dilakukan pada masyarakat pesisir pantai karena masih kurangnya kesadaran dan pengetahuan akan pentingnya menjaga kebersihan gigi dan mulut.

Masyarakat pesisir pantai menerapkan pengetahuan yang diperoleh dari penyuluhan sehingga dapat mengubah perilaku menyikat gigi yang salah dan dapat mengurangi angka kejadian resesi gingiva.

\section{DAFTAR PUSTAKA}

1. World Health Organization. World health statistic 2012. Geneva: WHO; 2012. p.51. 
2. Badan Penelitian dan Pengembangan Kesehatan. Laporan nasional Riskesdas 2018. Jakarta: Kemenkes RI, 2018; p. 181-207.

3. Krismariono A. Prinsip dasar perawatan resesi gingiva. Dentika Dent J 2014; 18(1):96.

4. Sunnati, Hakim FR, Nurlita F. Hubungan antara teknik menyikat gigi dengan resesi gingiva. Dent J. 2011;8(2):33299.

5. Dőrfer CE, Staehle HJ, Wolff D. Three-year randomized study of manual and power tootbrush effects on pre-existing gingival recession. Clinical Perio J 2016;43:512-3.

6. Zarra J. Status gingiva anak usia 14-15 tahun di daerah dataran tinggi dan di daerah pesisir pantai. eG. 2016;4(2):266.

7. Chrysantopoulus NA. Occurrence, extension, and severity of the gingival recession in a Greek adult population sample. Perio Implant Dent J. 2010;2(1):37-8.

8. Hammaci, N Basaran. Dental aesthetic index scores and perception of personal dental apparance among Turkish University Student. Eur Orthod J 2009;31(2):168-73.

9. Ikan melimpah dilaut, kemana nelayan kita. 2016. [cited 2019 June 28]. Available from: http://ristekdikti.go.id.

10. Rakhmanda A. Peran kelompok nelayan dalam perkembangan perikanan di Pantai Sadeng Kabupaten Gunung Kidul. Jurnal Sosiologi Pedesaan.
2018;6(2):94-104.

11. Siregar RS. Hubungan teknik menyikat gigi dengan terjadinya resesi gingiva pada mahasiswa FKG USU angkatan 2015 dan 2016 [Skripsi]. Medan: Universitas Sumatera Utara; 2017; p. 25.

12. Keumala C. Pengaruh penggunaan pasta gigi yang mengandung baking soda dengan pasta gigi yang mengandung fluor terhadap $\mathrm{pH}$ saliva pada murid kelas V SDN 24 Banda Aceh. Kesmas dan Ling Hidup J. 2017;2(2):55.

13. Triswari D, Pertiwi AD. Pengaruh kebiasaan menyikat gigi sebelum tidur malam terhadap skor indeks plak dan $\mathrm{pH}$ saliva. Insisiva Dent J. 2017;6(2):2.

14. Asmara AH. Perbedaan tingkat keparahan resesi gingiva masyarakat dataran tinggi dan masyarakat pesisir pantai (Studi kasus masyarakat Kecamatan Camba dan Kecamatan Bontoa Kabupaten Maros tahun 2014). Makassar: Universitas Hasuddin; 2014.

15. Rateitschack EM, Wolf HF, Hassel TM. Color Atlas Periodontology. New York: Thieme Inc, 1985; p. 115.

16. Beltran V, Mario W, Mario C. Effect of manual tooth brushing on gingival recession in an adult population saample in South of Chile. Odonto J 2014;8(3):461-7.

17. Sitanaya RI. Pengaruh teknik menyikat gigi terhadap terjadinya abrasi pada servikal gigi. J Media Kes Gigi 2017:16(1):42. 